\title{
ECONOMIC VALUATION USING TRAVEL COST METHOD (TCM) IN KILIM KARST GEOFOREST PARK, LANGKAWI, MALAYSIA
}

\author{
Matthew NK ${ }^{1}$, Shuib $\mathrm{A}^{2,}$ *, Ramachandran $\mathrm{S}^{2,3} \&$ Mohammad-Afandi $\mathrm{SH}^{2,3}$ \\ ${ }^{1}$ Department of Environmental Management, Faculty of Environmental Studies, Universiti Putra Malaysia, 43400 UPM, \\ Serdang, Selangor, Malaysia \\ ${ }^{2}$ Institute of Agricultural and Food Policy Studies, Universiti Putra Malaysia, Putra Infoport, 43400 UPM, Serdang, \\ Selangor, Malaysia \\ ${ }^{3}$ Faculty of Economics and Management, Universiti Putra Malaysia, 43400 UPM Serdang, Selangor, Malaysia
}

*mad.shuib@gmail.com

Submitted August 2017; accepted May 2018

\begin{abstract}
Kilim Karst Geoforest Park is a special conservation area within a Permanent Forest Reserve (PFR), consisting of limestone landscape, an extensive mangrove forest system, beaches, coastal wetlands and islands. However, the limestone, forest reserve and mangrove areas have been identified as environmentally sensitive, and are under threat by development activities. Currently, there is a lack of information on the economic benefits of the geoforest park, in terms of services. A demand model of international visitors to the Kilim Karst Geoforest Park (KKGP) was derived and compared the benefit estimated using both travel cost and consumer surplus adjustment techniques. The Travel Cost Method (TCM) has been employed to derive the demand model, whilst the concept of consumer surplus was used for value determination and comparison. The findings showed that the benefit estimated using travel cost adjustments, based on satisfaction attained, is $€ 288,000,000$, and number of hours spent in the park is $€ 141,000,000$, which was greater than that for the consumer surplus adjustment based on satisfaction attained $€ 278,640,000$ and number of hours spent $€ 123,840,000$. The study proposed the travel cost adjustment technique findings rather than the consumer surplus adjustment technique, since it was based on specific KKGP model estimation. In conclusion, the findings on the monetary value of the geoforest park will alert the community regarding the importance of conserving KKGP.
\end{abstract}

Keywords: Consumer surplus, demand, economic benefits, tourism economics

\section{INTRODUCTION}

A geoforest park is a special conservation area within a Permanent Forest Reserve (PFR). It has supreme geological and biological resources, is geared towards sustainable tourism practice, it promotes multidisciplinary research and enriches community awareness about the natural integration of various forest resources (Shaharuddin et al. 2004). The geoforest park concept in Langkawi Island was introduced by the Forestry Department of Peninsular Malaysia as a form of conservation that combines elements of forest and geology (minerals) (LADA 2016). On $1^{\text {st }}$ June 2007, Langkawi Island was gazetted by the United Nations Educational, Scientific and Cultural Organisation (UNESCO) Global Network of National Geoparks as one of the first geoparks in Southeast Asia. Langkawi Geopark includes three geoforest parks, namely, Dayang Bunting Marble, Kilim Karst and Machinchang
Cambrian Geoforest Parks (Halim et al. 2011). The geo-heritage conservation in the three geoforest parks are carried out under the jurisdiction of the Forestry Department of Peninsular Malaysia (LADA 2016). The Kilim Karst Geoforest Park (KKGP) is a world-class natural attraction containing a beautiful limestone landscape, an extensive mangrove forest system, lovely beaches, coastal wetlands and two islands (Langgun and Dendang) that are spectacular nature parks in themselves (LADA 2016). Unlike a protected national forest park, under the Geopark concept, controlled development at KKGP is allowed. Also, community participation is encouraged, particularly associated to tourism activities. Some of the issues at KKGP are related to the decline in the mangrove area, adverse impacts from ecotourism and threat to limestone (Shaharuddin et al. 2004). 
The failure to determine the value of the natural resources would lead to an underestimation of the true value of the resources, or for it to be considered to have zero value (Gürlük \& Rehber 2008). This, in turn, may prompt decision makers to use a particular site for other development activities that may result in damage to the site (Poor \& Smith 2004). In Langkawi, the mangrove forest at Kilim river, Kilim Geoforest Park, is threatened by mangrove clearing, mangrove conversion to commercial areas, residential areas, agriculture, aquaculture and the wake current (Shahbudin et al. 2012). Furthermore, increasing boat traffic, coastal development such as reclamation, erosion, accretion and sedimentation, which are mostly for ecotourism activities, have an ironically negative impact on the mangrove ecosystem in KKGP (Nabila et al. 2011). Consequently, over $8 \%$ (176.83 ha) of mangrove cover was degraded along Kilim River from its total area of 2153.07 ha between 1996 and 2008 (Shahbudin et al. 2012).

In general, although public awareness of the importance of conservation of natural resources has increased, understanding of the benefits of conserving the natural ecosystem is still low (Ahmad 2009). Thus, many people consider protecting forest resources, wildlife, land and water by not harvesting them has little value (Smith 1993). The situation has arisen most probably because the authorities or responsible parties do not value natural resources such as wetlands (mangrove areas, specifically) and their goods and services in appropriate and accurate economic and monetary terms (Azmi 2014). For goods that are exchanged in the market, price is often accepted as an indicator of benefit or value to the purchasers (Ahmad 2009). However, for goods that have no market price, the indicator of benefits is more difficult to estimate. Therefore, a majority of people (including the stakeholders) are not always aware of the value contributed by the geoforest park. This will lead to an incorrect evaluation on benefits and costs that the geoforest park can offer when compared with other land-use options.

Natural resources such as mangrove ecosystems in a geoforest park are vital to coastal communities. They prevent damage caused by tsunami waves, erosion and storms, and serve as a nursery for fish and other species that support coastal livelihoods (Yong 2014). Additionally, recreation is another vital activity in the mangrove ecosystem (Ahmad 2009). Thus, in Langkawi the existence of a pristine mangrove ecosystem in KKGP acts as an attraction to visitors.

Estimation of the economic benefits of recreational sites is crucial to politicians, policy makers and the general public, to enable them to integrate both ecological perspectives and economic considerations (Chee 2004). For example, in Langkawi Island, the limestone in KKGP can be used as building material, cement or mortar, used in the manufacture of ceramics as cheap fillers for plastics and construction of roads. Nonetheless, preservation of resources is carried out in KKGP, particularly the limestone and mangrove swamps, by prioritising rural tourism businesses instead of other development alternatives (Matthew 2015). Thus, the quantitative value derived from the estimation of the economic benefits could be used to justify investment worthiness of public funds in a cost-benefit analysis as a basis for geoforest park conservation in KKGP. In addition, findings on economic value of the park will alert the community regarding the importance of conserving the natural resources available at the park. The failure to conserve the natural resources will lead to depletion and eventual destruction of the natural resources in the geoforest park (Matthew 2015).

Valuation of natural resources such as mangrove is currently based on direct use value (DUV) and indirect use value (IUV), or identification of the tangible benefits of mangrove (Sharma et al. 2015). However, limited studies have been undertaken to determine the intangible benefits from mangrove, or in a broader scope, the wider geoforest park, based on a proper economic analysis to derive non-use value, specifically from international visitors. However, the use value of geoforest park services specifically at KKGP, Langkawi remains ambiguous to the stakeholders. The use value can be used to justify the importance of retaining the present population of mangrove ecology and limestone in the geoforest park that provide ecosystem services to the community, as compared to clearing the resource for alternative development use.

This study aims to derive the demand model of international visitors to KKGP and determine the intangible benefits attained by international visitors through travel cost adjustment and consumer surplus adjustment, based on the 
satisfaction attained and time spent at the site. Given the threat from alternative development options like industrial development, timber industries and aquaculture (eg. shrimp farming), it is crucial to show the economic benefits derived from geoforest park. Since KKGP is a non-market good, therefore, monetary value of the park is unknown for any justification to be made. Hence, Langkawi Development Authority (LADA) (2016) reported that no records were found about any forms of economic valuation, specifically on KKGP. The lack of information on the value of geoforest park services to policy makers would potentially threaten further deterioration of the sustainability of natural resources in Langkawi.

In general, there are a lot of studies in regards to the economic landscape assessment. Landscape can take the form of monetary values through indirect methods, such as Travel Cost and the Hedonic Technique which are based on the revealed preferences valuation (Cavailhês et al. 2009, Fezzi et al. 2014, Adili \& Robert 2016, Abideyo \& Chan 2017). On the other hand, there are direct methods like the Contingent Valuation Method and Choice Modelling based on the stated preferences valuation (Kaffashi et al. 2015, Sharahi et al. 2015). In the later approach, the willingness to pay for resource conservation will directly determine the monetary value.

\section{MATERIALS AND METHODS}

\section{Study Area}

The study area is situated between latitude $6^{\circ} 29^{\prime}$ to $6^{\circ} 23^{\prime} \mathrm{N}$ and longitude $99^{\circ} 48^{\prime}$ to $99^{\circ} 55^{\prime} \mathrm{E}$ at the northeast of part of Langkawi Island within the state of Kedah, Malaysia (Nabila et al. 2011). Kilim Geoforest Park is about 478 square kilometers occupied by mangrove forest, greenish mangrove swamps, the Kilim River, a limestone formation, narrow valleys, limestone cave tunnels and extensive wildlife (Matthew 2015, Nabila et al. 2011). It consists of the oldest limestone in the country, namely the setul formation, from over a million years ago. The KKGP features breath-taking landscapes of nearly vertical karstic hills with pinnacles of various shapes and sizes (GGN 2009). Mangroves species in this region are varied since there are at least 58 species, 39 genus and 23 families (Nabila et al. 2011).

\section{Data collection}

Data on use value from geoforest products and services were produced from a survey of international tourists using questionnaires. The questions in the survey related to variables such as age, education, income, occupation, trip details of the travel cost incurred to visit the geoforest park, the quality of the visit experience and willingness to pay for the park. A total of 300 tourists were selected as respondents by a purposive sampling method (Mangkay et al. 2013). The sample size was chosen by referring to a previous sample size table (Zikmund 2010), in which for a total of 126,982 tourists arrival, the appropriate number of the sample size was 300 . In regards to that, only those who had visited the park were chosen as respondents, consistent with the requirement of the method used. From the 300 samples, the proportion of male visitors amounted to $70.7 \%$ while the female visitors amounted to $29.3 \%$.

The possible explanation for the difference is that during the data collection period, only the heads of the families (fathers) were chosen as respondents, assuming that the heads of the families were in charge of the whole holiday trip (Ahmad 1994). Nonetheless, in case that the head of the family was not around, the mother or the eldest person in the family was chosen as the respondent (Syamsul 2010). The survey was conducted at KKGP within a duration of two weeks in November 2012 (Figure 1). KKGP was selected as the study site because the park is home to one of the best-kept and unique limestone mangrove forests in the world (LADA 2012).

\section{Individual travel cost model (ITCM)}

In this study, the ITCM model was used to analyse the derived data. In this model, the dependent variable was the number of trips per season or per year made by an individual to KKGP. The quantitative measurements included interval measurement scale for continuous data of variables in Equation 1, except for age and quality of life. The measurement unit for education was nominal, while the measurement for quality of park was based on an ordinal value (the five-point Likert scale). 


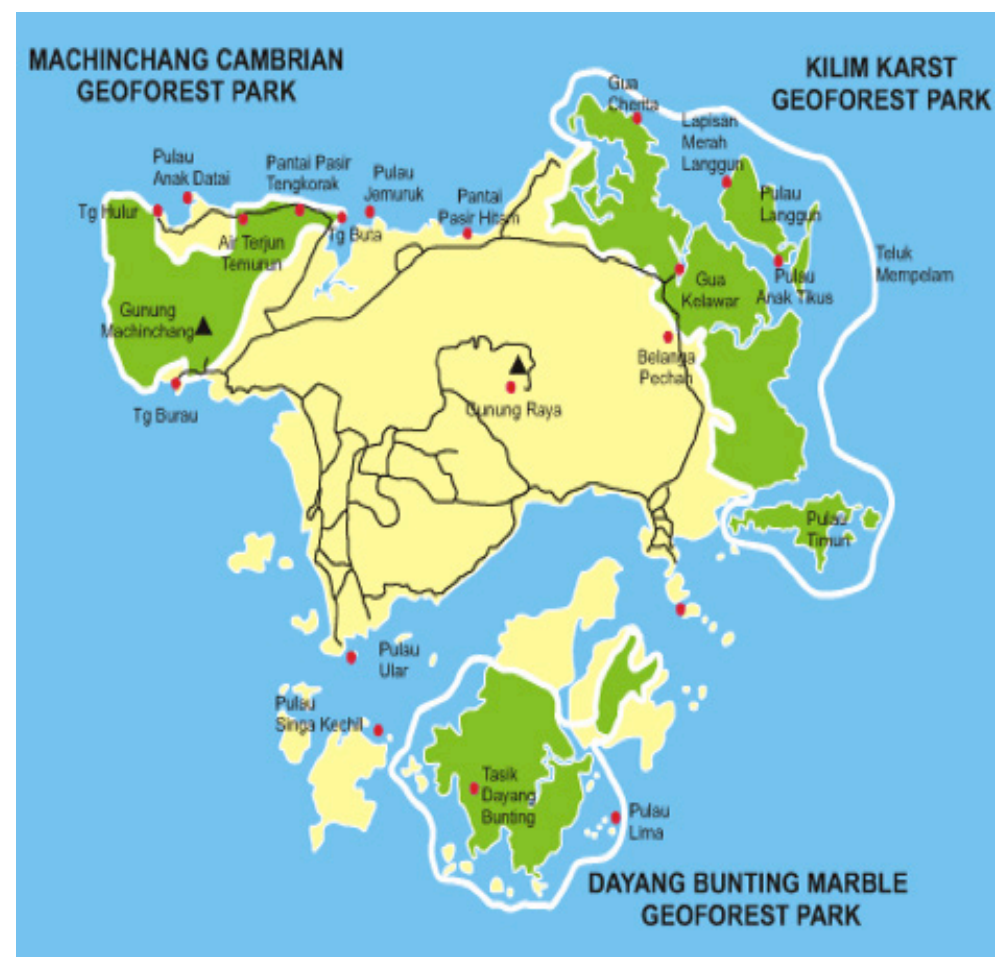

Figure 1 Location map of Kilim Karst Geoforest Park (KKGP) (LADA 2016)

The ITCM model can be explained as follows:

$$
\begin{aligned}
& \mathrm{V}=\beta_{0}+\beta_{1} \text { RITC }_{\mathrm{ij}}+\beta_{2} \text { TTimeC }_{\mathrm{ij}}+\beta_{3} \mathrm{MS}+ \\
& \beta_{4} \text { Age }+\beta_{5} \mathrm{Edu}+\beta_{6} \mathrm{GM}+\varepsilon
\end{aligned}
$$

where $\mathrm{i}=$ origin (main cities of respondents), $\mathrm{j}=$ Kilim Karst Geoforest Park, Langkawi, $\mathrm{V}=$ number of trips per year to Kilim Karst Geoforest Park, RITC $_{\mathrm{ij}}=$ total round trip travel cost of individual from $\mathrm{i}$ to site $\mathrm{j}$, TTime $_{\mathrm{ij}}=$ cost of travelling time of individual, $i$ to site $\mathrm{j}$, MS = quality of the Kilim Karst Geoforest Park as an indicator of satisfaction level measured by mean satisfaction, age $=$ age of individuals, $\mathrm{edu}=$ education level of individuals, GM gross monthly income of individuals, $\beta_{0}-\beta_{6}=$ coefficients to be estimated, $\varepsilon=$ random error.

In this study, there were four models developed based on the popular travel cost adjustment and consumer surplus adjustment techniques. Previous studies have utilised the travel cost adjustment technique while others have employed the consumer surplus adjustment technique (Beardsley 1971, Clough \& Meister 1991, Hajkowicz et al. 2000, Enyew 2003, Nillesen et al. 2005, Fleming \& Cook 2008, Tiantian 2009, Nde 2011). The first Langkawi model was based on travel cost to Langkawi (travel cost adjustment and consumer surplus adjustment techniques represented by Equation 2 and 3), followed by specific KKGP models for travel cost adjustment based on satisfaction attained (Equation 4) and number of hours spent in the park (Equation 5).

Referring to equations 2, 3, 4 and 5, it was noticed that only travel cost adjustment technique were performed in equation 2 (Langkawi model), 4 and 5 (KKGP models), consistent with available valuation literature on travel cost method (Clough \& Meister 1991, Fleming \& Cook 2008, Nillesen et al. 2005). However, the consumer surplus adjustment were only performed in equation 3 (Langkawi model) since the technique does not require specific KKGP models shown in equation 4 and 5 . Therefore, for the consumer surplus adjustment technique, the specific value attained by visitors to KKGP was identified by directly estimating equation 3 (Langkawi model). Then, the consumer surplus value for Langkawi was determined from the estimation of equation 3 using a formula (equation 7). The consumer surplus value for Langkawi was directly apportioned to KKGP based on satisfaction attained from number of hours spent in KKGP (equation 6). 
Travel cost to Langkawi based on travel cost adjustment (equation 2) or consumer surplus adjustment (equation 3):

$$
\begin{aligned}
& \text { Vis }=f\left(\text { RITC }_{\text {LKWij }}, \text { TTimeC }_{\text {ij }}\right. \text { MS, Age, Edu, } \\
& \text { GM, } \varepsilon)
\end{aligned}
$$

Travel cost to Kilim based on satisfaction at the park (travel cost adjustment):

Vis $=f($ RITSATij, TTimeCij, MS, Age, Edu, GM, $\varepsilon$ )

Travel cost to Kilim based on number of hours at the park (travel cost adjustment):

Vis $=f($ RITCHOURSij, TTimeCij MS, Age, Edu, GM, $\varepsilon$ )

The specific round trip travel cost to Langkawi Island in equation 2 and 3 (Langkawi model) for both (travel cost adjustment and consumer surplus adjustment) were calculated by adjusting the travel cost from the point of origin (home of the respondent) to Langkawi, which included the travel cost incurred to other destinations prior to arriving in Langkawi. The adjustment was made by multiplying the total round trip travel cost with the number of days the respondents planned or had spent in Langkawi, as a proportion of the total number of days the respondents would spend away from home, until the last day at Langkawi, as shown below:

Round trip travel cost from home until Langkawi

$\times\left(\frac{\text { Number of days in Langkawi }}{\text { Total days from home until the end of the trip in Langkawi }}\right)$

Next, for determination of the specific value attributable to KKGP, the following techniques were deployed for both travel cost adjustment and consumer surplus adjustment. For travel cost adjustment, the specific travel cost to KKGP in KKGP models (equation 4 and 5) were multiplied with the adjusted travel cost to Langkawi using the formula in equation 6 (satisfaction attained and time spent in KKGP), by the visitors respectively. Likewise, for consumer surplus adjustment, the two techniques were also deployed. The consumer surplus value for Langkawi derived from the estimation of Langkawi model was directly multiplied with the following techniques to reveal the consumer surplus value for KKGP.
The two techniques below have been adapted from Fleming \& Cook (2008).

1. The time spent in the park as a proportion to the overall recreational hours spent at or would be spent in Langkawi, by assuming that the time available for recreation in a day is 8 hours, consistent with the assumption made by Tiantian (2009)

2. The satisfaction from visiting KKGP as a proportion of the total satisfaction obtained from visiting Langkawi Island (as reported by the respondents)

The assumption made in the first approach (1) was that the benefits obtained by the visitors is proportional to the expenditure and time allocated for visiting the site (Beardsley 1971). Thus, the increase in the length of stay or time spent would stimulate the opportunity to obtain more value, and consequently determine the benefit obtained by the visitors. Some of the limitations of the approach were factors such as weather conditions, fixed trip itineraries and lack of prior information regarding the site's true attraction that may influenc the time spent at the site and the value attached to the site (Clough \& Meister 1991). For the second approach based on satisfaction attained (2), an assumption was that decisions made to travel to a particular site were based on the visitors hope to obtain positive utilities (Nillesen et al. 2005). In addition, the assumption was that visitors were able to rank the sites they visited based on their preferences or the weightage they allocated for the sites.

\section{Sampling and design}

The respondents were chosen mainly from the KKGP and Langkawi International Airport within duration of two weeks in November 2012. In regards to that, only those who had visited KKGP were chosen as respondents. Finally, only the heads of the groups were chosen as respondents. Pertaining to that, Ahmad 1994 suggested that if the respondents were from a group, then the head of the group was selected as the respondent, as the data accumulated from the leader of a group would represent it. Out of 330 respondents, 30 questionnaires were discarded due to irrelevant information. Thus, 300 responses were used for further analysis. Data were analysed using SPSS Statistical Package for Social Sciences (version 21). A Poisson regression 
analysis was conducted to run the ITCM model using Limited Dependent Variable (LIMDEP) software version 4 .

\section{DISCUSSION AND RESULTS}

The findings in this study were an extension of the analysis conducted by Matthew et al. (2013), which proposed the full model for ITCM, however, it only estimated the basic TCM model in which only the travel cost variable was tested. The study found that the value of Pseudo $\left(R^{2}\right)$, which is the measure of fit for a model, was very low or amounted to $8 \%$ based on the travel cost to Langkawi model, and $12 \%$ and $9 \%$ using both the satisfaction and hour's models. Hence, this study hoped that the inclusion of other demand shifting variables would increase the Pseudo $\left(R^{2}\right)$ value. Consistently, Pseudo $\left(\mathrm{R}^{2}\right)$ was found to be greater than $30 \%$ for all three models, which was more than the findings from Matthew et al. (2013), using the basic TCM model.

The entire travel cost variables in the three models in Table 1 were found to be significant with a negative coefficient, using Poisson regression analysis. The negative coefficient implied a downward sloping demand curve from left to right. Similarly, Syamsul (2010), in a study to value the recreational benefits of Perlis State Park in Malaysia, found a negative coefficient in the Poisson regression analysis for ITCM. Thus, visitors who incur more travel cost would make fewer visits to the park. For instance, a $10 \%$ increase in the travel cost would cause a reduction in visits by $0.001 \%$ to Langkawi Island, $0.004 \%$ to the KKGP based on satisfaction model, and $0.009 \%$ to the KKGP based on the number of hour model. By assuming a $10 \%$ increase in the travel cost for all international visitors to Langkawi in $2012(126,982)$ at the average travel cost of RM 4,264, the reduction in the number of visits would be 1,269 . Later, by assuming a $10 \%$ increase in the travel cost for all international visitors to the KKGP in $2012(126,982)$, at the average travel cost of RM 1,132 based on satisfaction, and RM 244 based on hours, the reduction in the number of visits would be 508 based on satisfaction model and 1,143 based on hours model.

The findings were consistent with the demand theory, in which an additional increase in travel cost would inversely influence the number of visits to the park. The quality of the site measured by satisfaction gained (MS) variable was found to

Table 1 Estimation of Poisson regression

\begin{tabular}{llll}
\hline Variables & Langkawi Island & KKGP (satisfaction) & KKGP (hours) \\
\hline (Constant) & 1.712 & 1.618 & 1.672 \\
& $(4.645)^{* *}$ & $(4.378)^{* *}$ & $(4.773) * *$ \\
RITC $^{1}$ & $-0.123 \mathrm{E}-03$ & $-0.440 \mathrm{E}-03$ & $-0.896 \mathrm{E}-03$ \\
& $(-3.427)^{* *}$ & $(-3.249)^{* *}$ & $(-1.96)^{* *}$ \\
TTimeC $^{2}$ & Not tested & Not tested & $-0.436 \mathrm{E}-03$ \\
& & & $(-2.040)^{* *}$ \\
MS $^{3}$ & -0.362 & -0.338 & -0.435 \\
& $(-4.842)^{* *}$ & $(-4.473)^{* *}$ & $(-5.890)^{* *}$ \\
Age $^{4}$ & $0.712 \mathrm{E}-02$ & $0.711 \mathrm{E}-02$ & $0.609 \mathrm{E}-02$ \\
& $(2.729)^{* *}$ & $(2.725)^{* *}$ & $(2.352)^{* *}$ \\
Edu $^{5}$ & $0.489 \mathrm{E}-01$ & $0.491 \mathrm{E}-01$ & $0.507 \mathrm{E}-01$ \\
& $(4.209)^{* *}$ & $(4.226)^{* *}$ & $(4.390)^{* *}$ \\
GM $^{6}$ & $-0.229 \mathrm{E}-04$ & $-0.230 \mathrm{E}-04$ & Not tested \\
& $(-2.514)^{* *}$ & $(-2.524)^{* *}$ & \\
Pseudo R $^{2}$ & 0.386 & 0.382 & 0.385 \\
Log likelihood function & -781.284 & -823.293 & -853.232 \\
\hline
\end{tabular}

\footnotetext{
** Significant at 5 percent level and in brackets is t-statistic value whereas that without brackets is coefficient value of the variable; ${ }^{1}$ total round trip travel cost of individual from i to site $\mathrm{j},{ }^{2} \operatorname{cost}$ of travelling time of individual, i to site $\mathrm{j},{ }^{3}$ quality of the Kilim Karst Geoforest Park as measured by mean satisfaction, ${ }^{4}$ age of individuals, ${ }^{5}$ education level of individuals, ${ }^{6}$ gross monthly income of individuals
} 
be significant at $95 \%$ level of confidence with a negative beta coefficient in all of the three models. Similarly, Syamsul (2010) found a negative beta coefficient in the Poisson regression analysis for ITCM. The negative coefficient implies that an increase in visitor satisfaction levels would shift the demand for goods inwards. For instance, a $1 \%$ increase in the satisfaction of visitors would reduce the visits to the park by $0.44 \%$ based on KKGP hours model.

This implies that, the more satisfaction gained from the resources available in KKGP as proportionate to the overall satisfaction obtained in Langkawi, the fewer the number of visits there would be to the park. Nonetheless, the sign of the coefficient is beyond the expectation made. This could be because the high satisfaction attained from the visit may encourage them to visit other geoparks in Langkawi, eg. Matchinchang and Dayang Bunting Marble Geoforest Parks, instead of returning to KKGP, in hopes of attaining better or more satisfaction there. Also, they may want to visit other geoparks in the world, eg. Sennongjia and Yanqing (China), Oki Islands (Japan), Hondsrug (Netherlands), Azores (Portugal), etc. The age variable was found significant at $95 \%$ level of confidence with a positive coefficient in all of the three models. Likewise, Chae et al. (2012) found a positive coefficient for the income variable. This implies that the number of visits to the site is positively related to the age of the visitors. Hence, the demand for goods would shift outwards for an increase in the age of the visitors.

A positive coefficient found in the education variable suggested that the demand for goods will shift outwards for visitors with higher levels of education. The finding was consistent with Okojie \& Amujo (2011) who found a positive relationship between the education level of visitors and the demand for the site. For instance, based on the adjusted Kilim hours model, a fiveyear increase in education level of a respondent increased the visits by 0.25 . Hence, the increase in the visits, based on the total number of international visitors to KKGP in 2012 (126,982), would be 31,746 visits. The income (GM) variable is a demand shifter. The variable measures the percentage change in the visits as a response to the changes in the income level of the visitors. The variable was found significant at $95 \%$ level of confidence with a negative coefficient, only for Langkawi and Kilim, based on satisfaction models.
Similarly, Edwards et al. (2011) and Chae et al. (2012) found a negative coefficient for the income variable. The negative beta coefficient suggests that the demand for goods would shift inwards followed by an increase in the income of the visitors. Thus, KKGP is an inferior good to international visitors. Consequently, an increase in the income of visitors would encourage them to visit other superior destinations. For instance, a $10 \%$ increase in the income of visitors would cause the visits to be reduced by $0.000229 \%$ for Langkawi and $0.00023 \%$ for Kilim based on satisfaction models. Hence, by assuming the monthly income for all of the international visitors to KKGP in $2012(126,982)$, increased by $10 \%$, the reduction in the number of visits would be 23 based on Kilim satisfaction model. The time cost variable was significant at $95 \%$ level of confidence and inversely related to visits to the park, in the Kilim hour model. The time cost variable based on sutisfaction models was not tested in both Langkawi and Kilim due to a high correlation $(>0.9)$ with income variable, as suggested by Pallant (2011).

This would have influenced the beta coefficient value of the travel cost variable, since time cost incurred to a destination is part of the travel cost incurred by the visitors. As a consequence, the failure to take into account the travel time cost variable would have overestimated the consumer surplus estimation for both models. Nonetheless, the time cost variable was estimated in the Kilim hour model, and therefore, a higher (Pseudo $\mathrm{R}^{2}$ ) was found. This suggested that visits to the park by visitors would reduce, following an increase in the opportunity cost of time. For instance, based on travel cost to Kilim, adjusted based on hours at the park, a $10 \%$ increase in time cost incurred by visitors would reduce the visits by $0.0044 \%$.

The consumer surplus was estimated using coefficient of the total travel cost variable $\left(\mathrm{b}_{\mathrm{Ttc}}\right)$ which was obtained through the summation of (trip cost variable, RITC and time cost variable, TTimeC) using the formula below (Ahmad 1994, Syamsul 2010).

$$
\begin{gathered}
\text { CS per visit }=-1 / \mathrm{b}_{\mathrm{Ttc}} \\
\mathrm{b}_{\mathrm{Ttc}}=\mathrm{b}\left(\left(_{\text {trip cost } / \text { RITC }}\right)+\mathrm{b}(\text { time cost } / \mathrm{TTimeC})\right.
\end{gathered}
$$

Later, the average consumer surplus value per person/trip/year was determined by dividing the CS per visit/group with the average visit/ average number of people in a group, which 
was 3.48. The adjustment was made based on the suggestion by Chakraborty \& Keith (2000), who divided the CS per visit with the average visit in a study to determine the demand and economic value of Mountain Biking in Moab, Utah. Later the consumer surplus per visit/person/year was multiplied with the total number of international visitor arrivals to KKGP in $2012(126,982)$ to obtain the total consumer surplus value or economic value of the park. Referring to Table 2 , for the travel cost adjustment, the specific travel cost to Langkawi (Langkawi model) was multiplied with the average satisfaction attained (SAT) and average time spent at the KKGP as a portion of the overall satisfaction or days in Langkawi to come up with specific KKGP models. Thus, the consumer surplus value was determined based on a respective significant beta value of the trip cost variable and time cost variable for KKGP. Whereas, for consumer surplus adjustment, the specific value allotted by visitors to the park was determined by directly multiplying the consumer surplus value of Langkawi with SAT and average time spent at KKGP as a portion of the overall satisfaction or days in Langkawi.

The results showed that the economic value of KKGP based on travel cost adjustment was greater than consumer surplus adjustment technique. Furthermore, in both adjustment techniques the value derived using SAT was found to be greater than using the time spent in the park (hours). This was because the average satisfaction attained value was twice greater than the average time spent at KKGP.

\section{CONCLUSION}

This study revealed that the economic value of KKGP is large. Adjustment to the travel cost incurred by international visitors, for whom the KKGP was not the only site visited, was made possible through the Langkawi model based on travel cost adjustment and consumer surplus adjustment techniques. Since KKGP is a part of Langkawi Island, it was crucial to develop the Langkawi model in which it was useful to determine the specific value attributed by the tourists to KKGP. This examination is crucial since the failure to adjust the travel cost incurred would overestimate the consumer surplus or benefit obtained by the tourists. For travel cost adjustment, the estimation results for specific KKGP models showed that the time spent model outperformed the satisfaction model statistically. Therefore, for the travel cost adjustment technique, the present study proposed to the management of the park on the consumer surplus value derived from the estimation of the time spent model, as compared to satisfaction model. Likewise, in comparison of the economic value derived from travel cost adjustment and consumer surplus adjustment techniques, the study proposed findings from the travel cost adjustment technique, since it was based on the specific KKGP models estimation. In terms of limitations, the present study did not incorporate the effect of alternative sites available in Langkawi, such as Dayang Bunting Marble and Machinchang Cambrian Geoforest Parks, as well the onsite-costs put into the demand model which act as demand shifters. This would have led to the overestimation of the consumer surplus value in the present study. Therefore, a future study may want to include the effect of alternative sites and onsite-cost as independent variables in the ITCM model.

In addition, similar studies should also be undertaken in other geoforest parks, namely the Machinchang Geoforest Park and Dayang Bunting Marble Geoforest Park. Such studies, in the future, will provide comparative analysis for future conservation of these areas. Findings on the monetary value of the geoforest park will alert the community regarding the importance of conserving KKGP. In addition to this, these findings will help in justifying the utilisation of land withim the park for mangrove, limestone and similar conservation purposes, instead of utilising it for other forms of alternative development that will eventually contribute

Table 2 Economic value of Kilim Karst Geoforest Park, Langkawi

\begin{tabular}{lll}
\hline Model & Travel cost adjustment & Consumer surplus adjustment \\
\hline TCLKW & $€ 1,032,000,000$ & $€ 1,032,000,000$ \\
TC Kilim (SAT) & $€ 288,000,000$ & $€ 278,640,000$ \\
TC Kilim (Hours) & $€ 141,000,000$ & $€ 123,840,000$ \\
\hline
\end{tabular}


to the damage and destruction of the natural resources at KKGP. The outcome of this study can be utilised for various aspects of geoforest park and tourism development related to policy implementation (Carlo 2014, Siow et al. 2015, Scutariu et al. 2017, Shin et al. 2017). Local government involvement and local community's participation should be equally stressed (Nair et al. 2012, Kunasekaran et al. 2013).

\section{ACKNOWLEDGEMENTS}

The research was partially funded by Geran Universiti Putra Malaysia (GP-IPS/2015/ 9469600).

\section{REFERENCES}

ADILI ZY \& RoBert N. 2016. Economic valuation of recreation use value of Kilimanjaro National Park, Tanzania. Journal of Ecosystem Ev Ecography 6: 220.

Ahmad S. 1994. Demand for and value of outdoor recreation in Langkawi by domestic visitors. $\mathrm{PhD}$ thesis, Universiti Putra Malaysia, Selangor.

Ahmad S. 2009. Recreational values of mangrove forest in Larut Matang, Perak. Journal of Tropical Forest Science 21: 81-87.

Azmi M. 2014. Valuing the potential economic value of mangroves resources in Setiu wetlands, Terengganu, Malaysia: A preliminary findings. International Journal of Education and Research 2: 487-504.

BEARDSLEY W. 1971. Bias and non-comparability in recreation evaluation models. Land Economics 47: 175-180.

Cavailhès J, Brossard T, Foltête JC et al. 2009. GIS-Based hedonic pricing of landscape. Environmental Resource Economics 44: 571-590.

CARLo A. 2014. Sustainable tourism in practice : Promoting or perverting the quest for a sustainable development. Journal of Sustainability 6: 2562-2583.

Chae D, Wattage P \& Pascoe S. 2012. Recreational benefits from a marine protected area: A travel cost analysis of Lundy. Tourism Management 33: 971-977.

Chakraborty \& Keith. 2000. Estimating the recreation demand and economic value of mountain biking in Moab, Utah: An application of count data models. Journal of Environmental Planning and Management 43: 461-469.

CHEE YE. 2004. An ecological perspective on the valuation of ecosystem services. Biological Conservation 120 : 549-565.

Clough PWJ \& Meister AD. 1991. Allowing for multiple-site visitors in travel cost analysis. Journal of Environment Management 32: 115-125.

Edwards P, Parsons G \& Myers K. 2011. The economic value of viewing migratory shorebirds on the Delaware Bay: An application of the single site Travel Cost Model using on-site data. Human Dimensions of Wildlife 16: 435-444.

ENYEw S. 2003. Valuation of the benefits of out-door recreation using the Travel Cost Method: The case of Wabi-Shebele Langano recreation site. MSc Thesis, Addis Ababa University, Addis Ababa.

Fezzi C, Bateman IJ \& Ferrini S. 2014. Using revealed preferences to estimate the value of travel time to recreation sites. Journal of Environmental Economics and Management 67: 58-70.

Fleming CM \& Cook A. (2008). The recreational value of Lake McKenzie, Fraser Island: An application of the travel cost method. Tourism Management 29: 1197-1205.

GGN (Global Geoparks Network). 2009. What is a geopark. https://en.unesco.org/.

GürLük S \& Rehber E. 2008. A travel cost study to estimate recreational value for a bird refuge at Lake Manyas, Turkey. Journal of Environmental Management 88: 1350-1360.

Hajkowicz SA, Mcdonald GT \& Smith PN. 2000. An evaluation of multiple objective decision support weighting techniques in natural resource management. Journal of Environmental Planning and Management 43: 505-518.

Halim SA, Komoo I \& Omar M. 2011. The geopark as a potential tool for alleviating community marginality: A case study of Langkawi Geopark, Malaysia. The International Journal of Research into Island Cultures 5: 94-113.

Kaffashi S, Radam A, Shamsudin M, Yacob M \& Nordin N. 2015. Ecological conservation, ecotourism, and sustainable management: The case of Penang National Park. Forests 6: 2345-2370.

Kunasekaran P, Gill SS, Talib AT \& Maarof R. 2013. Culture as an indigenous tourism product of Mah Meri community in Malaysia. Journal of Sustainable Development 5: 1-17.

LADA. 2012. Background of Langkawi Development Authority. http://www.lada.gov.my/v2/maklumat korporat/profil/latar-belakang-lada.

LADA. 2016. Langkawi Geopark. https://www.lada.gov.my/ mengenai-kami/produk/langkawi-unesco-globalgeopark.

Mangkay SD, Harahab N, Polit B \& Soemarno. 2013. Economic valuation of mangrove forest ecosystem in Tatapaan. IOSR Journal of Environmental Science, Toxicology And Food Technology 5: 51-57.

MatTHEW NK. 2015. Economic valuation of Kilim Karst Geoforest Park, Langkawi, Malaysia. MSc Thesis, Universiti Putra Malaysia, Selangor.

Matthew NK, Ahmad S, Ramachandran S \& Syamsul HMA. 2013. Demand model of international visitors to the Kilim Karst Geoforest Park, Langkawi: Application of ITCM Model. Journal of Applied Economics and Business1: 51-66.

Nabila GF, Faridah-Hanum I, Abdul Kudus K \& Nazre M. 2011. Assessment of floristic composition of Kilim Geoforest Park, Langkawi, Malaysia. Journal of Agricultural Science 4: 23-34.

Nair MB, Ramachandran S, Ahmad S, Syamsul HMA \& Nair V. 2012. Multi-Criteria decision making approach for responsible tourism management. Malaysian Forester 75: 135-146.

NDE TP. 2011. Non-market valuation of beach recreation using the Travel Cost Method (TCM) in the context of the developing world: An application to visitors of the Ngoé Beach in Kribi, Cameroon. MSc Thesis, Swedish University, Sweden. 
Nillesen E, Weseller J \& Cook A. 2005. Estimating the recreational use value for hiking in Bellenden Ker National Park, Australia. Journal of Environmental Management 36: 311-316.

OкоJIE LO \& ORISAJIMI OJ. 2011. Valuation of the recreational benefits of Old Oyo National Park, Nigeria: A travel cost method analysis. Journal of Food Agriculture andEnvironment 9: 521-525.

PaLLANT J. 2011. SPSS Survival Manual. A step by step guide to data analysis using the SPSS for windows (version 10). Open University Press, Buckingham.

POOR PJ \& SMITH JM. 2004. Travel cost analysis of a cultural heritage site: The case of historic St. Mary's City of Maryland. Journal of Cultural Economics 28: 217-229.

Scutariu A, Nastase C \& Popescu M. 2017. Perspectives of sustainable development of tourism in the NorthEast Region of Romania. Journal of Sustainability 9: $1-14$.

Shaharuddin MI, Komoo I, Mohd Shafee L. 2004. Geoforest Park: An Innovative approach towards geological heritage conservation within permanent reserved forest of Malaysia. UKM Press, Bangi

Shahbudin S, Zuhairi A \& Kamaruzzaman BY. 2012. Impact of coastal development on mangrove cover in Kilim river, Langkawi Island, Malaysia. Journal of Forestry Research 23: 185-190.

Sharahi MK, Mohamadi MH \& Abedini A. 2015. Estimating the outdoor recreational value of Chitgar Forestial Park of Tehran with the use of Contingent Valuation Method. Open Journal of Ecology 4: 64-75.
Sharma B, Rasul G \& Chettri N. 2015. The economic value of wetland ecosystem services: Evidence from the Koshi Tappu Wildlife Reserve, Nepal. Ecosystem Services12: 84-93.

Shin H, Kim HN \& Son J. 2017. Measuring the economic impact of rural tourism membership on local economy: A Korean Case Study. Journal of Sustainability 9: 1-13.

Siow ML, Ramachandran S, Ahmad S \& Syamsul HMA. 2015. Adapting evidence-based intervention in rural tourism policies: pragmatic benchmarking considerations for tourism business operations in Semporna, Sabah, Malaysia. Worldwide Hospitality and Tourism Themes 7: 473-485.

Sмітн VK. 1993. Nonmarket valuation of environmental resources :An interpretive appraisal. Land Economics 69: 1-26.

Syamsul HMA. 2010. Valuing recreational benefits of Perlis State Park, Malaysia using travel cost method. Unpublished PhD. Dissertation, Universiti Putra Malaysia, Selangor.

Tiantian. 2009. An Application of Travel Cost Method to Yuelu Mountain Park in Changsha, China. MSc thesis, University of Helsinki, Finland.

YonG C. 2014. Deforestation drivers and human rights in Malaysia. https://rightsanddeforestation.org/wpcontent/uploads/2018/02/Malaysia-deforestationdrivers-and-human-rights.pdf.

Zikmund. 2010. Business Research Methods, Eight Editions. Canada: South Western Cengage Learning. Cengage, Boston. 


\section{Appendix}

\section{QUESTIONNAIRE}

\section{Travel cost}

1. For this question, please choose the type of visitors that you belong to based on the options below (I or II)

(I) Single destination visitors: Visitors who visit only Langkawi

(II) Multiple destination visitors: Visitor who Langkawi is only one of the many destinations for the holiday trip

1) Single destination visitors

i) Where was your departure city and the name of the airport/ railway station? (E.g., Los Angeles, Los Angeles international airport etc.)

ii) Which airlines did you use to travel to Malaysia? (E.g., British Airways, Air Asia, KLM, Qantas etc.)

2) Multiple destination visitors

i) Kindly indicate the flow of your journey and the type of transportation used, from your home to Langkawi

(E.g., Los Angeles $\rightarrow$ Singapore (Flight), Singapore $\rightarrow$ Kuala Lumpur (Flight), Kuala Lumpur $\rightarrow$ Penang (Flight), Penang $\rightarrow$ Langkawi (ferry)

ii) Based on question $2 \mathrm{i}$ ) please indicate the name of the airport or railway station that you have been to until the (point of entry in Malaysia only).

(E.g., Los Angeles international airport $\rightarrow$ Changi airport $\rightarrow$ KLIA airport)

2. If you bought the ticket for plane or train via online, please indicate the name of the website. (E.g., www. expedia.com.my). If you did not buy online or could not remember, please move to the next question.

3. If you have not visited Langkawi which alternative site would you visit in Malaysia?

4. There are many attractions in Langkawi; despite is visiting the Kilim Karst Geoforest Park, Langkawi your main objective?
( )
1) Yes
$(\quad)$
0) No

5. Is this your first visit to Kilim Karst Geoforest Park, Langkawi?
$(\quad)$
1) Yes
( )
0) No
* If yes please skip question 11 and move to question 12 
6. If no, kindly indicate the number of times you have been to Kilim Karst Geoforest Park, Langkawi since the establishment of Kilim as a geoforest park by United Nations Educational, Scientific and Cultural Organization (UNESCO) in 2007. (Including current visit)

Number of visits $(\quad)$

7. How long was your journey from home to the departure airport or railway station whereby the journey to your first holiday trip destination began?

Hours/minutes

8. How long will your trip from your home until the last day at Langkawi be?

Days/ Weeks/ Months

9. How long have you stayed or planned to stay in Langkawi?

Days/Weeks

10. How long have you spent at this park?

\section{Hours/minutes}

11. Please indicate the travel cost from your home to the departure airport or railway station whereby the journey to your first holiday trip destination begins?

(E.g., taxi fare/ bus fare/ airfare or if you use private car indicate the fuel cost).

(RM or your currency)

12. Recreational fee/ number of hours at the site (RM or your currency/ hours)

13. What proportion would you allocate your enjoyment at Kilim Karst Geoforest Park, Langkawi out of the total enjoyment in Langkawi for recreational purposes? (E.g., 10\%, 20\% etc.) 